\title{
CONy: a new perspective for readers of JNT
}

\author{
Amos D. Korczyn
}

Published online: 25 February 2011

(C) Springer-Verlag 2011

\section{(2) \\ CDNY \\ THE WORLD CONGRESSES ON CONTROVERSIES IN NEUROLOGY}

I believe that every argument has a counter argument (Howard Jacobson, 2010).

The way knowledge advances is by finding new truths, and by discarding old beliefs. There is more than one way to progress, but the basic one is to question previously held views. The Jewish Talmudic scholars, just as the Greek sophists and, more importantly, the Socratic dialect followers, headed and developed this method. This method is invaluable in science, as well as in medicine.

Debates are frequently used by scientists, but having meetings specifically for this purpose is a new concept. Controversies in Neurology (CONy) is an annual meeting dedicated just to that. The CONy Congress functions as a unique forum for international experts to share and compare experiences, in order to outline appropriate diagnostic methods and treatments for neurological disorders. It is embarked upon primarily to facilitate effective debates on unresolved clinical and therapeutic dilemmas, supported by evidence-based medicine and the opinions of experts. These congresses have attracted much attention over the years with thousands of clinicians who not only learned, but also enjoyed the programs. Our four meetings so far in Berlin, Athens, Prague and Barcelona, and future ones in Beijing and Vienna, deserve a wider audience and we are delighted to launch this new section of the Journal of Neural Transmission (JNT) which will be devoted to debates emanating from our congresses.

We begin with the debate "AED discontinuation may not be dangerous in seizure-free patients" (E. Beghi and D. Schmidt), while future issues of the JNT will have debates on "Asymptomatic carotid stenosis: Intervention or just stick to medical therapy (G. Chrysant, L. Hirt and J. Streifler), "Substantia nigra hyperecogenicity is a risk marker for PD" (D. Berg and U. Walter), "The origin of migraine attacks" (L. Vecsei and E. Shevel), "What is the best treatment for advanced fluctuating PD" (S. Chabardes and R. Hilker) and hopefully many more.

We are grateful to the eminent neurologists who have contributed to CONy and now agree to present their views and experiences in articles for you, the readers of JNT.

Professor Amos D. Korczyn

CONy Chairman

Editor, Controversies in Neurology Section

Journal of Neural Transmission

Professor Peter Riederer

Editor in Chief

Journal of Neural Transmission

A. D. Korczyn ( $\square$ )

Tel Aviv University, Tel Aviv, Israel

e-mail: amoskor@post.tau.ac.il 